\title{
SBP's Home Remittance Policies and its Effects in Pakistan: A Study of the Last Ten Years (2001-2010)
}

Syed Muhammad Hasan

Dr. Mustaghis-ur-Rahman

\begin{abstract}
Only second to exports income, home remittances are the bloodline of generating foreign reserves for any country. The remittance received from the expatriate workers community is and has always been the vital source of foreign exchange for the labor exporting countries. These remittances become more useful if they flow through the formal banking channels. In case, if the remittances flow through the informal channels, they create a parallel economy. During the last ten years (2001 - 2010), SBP has taken several valiant steps to increase home remittance volume through banking channel. This exploratory study documents the extraordinary growth in the home remittance volume with respect to the SBP's favorable policies. However, there could be some other influencing factors as well which might have boosted the volume of remittances. The phenomenon is studied to understand the effectiveness of the SBP home remittance policies and its implications to increase the volume of home remittances routed via banking channel in Pakistan for the last one decade. SBP policies are mainly focused to liberalize exchange rate differential among remittance business competitors, to attract remittances with minimum or no charges via banking system due to eligible remittance incentive scheme, to revamp existing and increasing foreign remitting arrangements (partners) with domestic banks, to improve the IT infrastructure, Payment Settlement System and Quality of Home Remittance Products/Services in the Pakistani banks to facilitate the beneficiaries in least possible turnaround time.
\end{abstract}

Keywords: Home remittance, Pakistani expatriates, Pakistan remittance initiative, cash over counter and credit to account payments, hundi and hawala.

\section{Introduction}

The remittance received from the expatriate workers community has always been the vital source of foreign exchange for the labor exporting countries (Nishat and Bilgrami, 1991). These remittances become more useful if they flow through the formal banking channels. In case, if the remittances flow through the informal channels, they create a parallel economy (Straubhaar, 1988). These forms of informal channels for the remittances are common in Pakistan and other countries like Egypt, Sudan and Philippines (Abella, 1989).

A major portion of workers' remittances flow through the unofficial or 'hundi/hawala' networks in Pakistan. Hundi is an illegal financial instrument that is used to transfer funds from one place to another. It started during the bygone days of Kings and British Rule in the subcontinent whereas hawala is an illegal money transfer services operated by money brokers around the world. The funds are transferred from one place to another without moving the original funds or using banking channel. According to SBP, during financial year July 2010-June 2011, the home remittance volumes routed through

Syed Muhammad Hasan is working at the National Bank of Pakistan, m.hasan@nbp.com.pk Dr. Mustaghis-ur-Rahman is Professor \& MS/PhD Coordinator of Management Sciences Dept. at SZABIST Karachi, mustaghis@szabist.edu.pk

\begin{tabular}{llll|l}
\hline Journal of Independent Studies and Research - MSSE & Volume 10 & Number 1 & January 2012 & 15
\end{tabular} 
banking channel was US $\$ 11.2$ billion (SBP Press Release, 2010). After 9/11, the flow of home remittances to Pakistan has increased tremendously. Despite global financial crisis, Pakistan is among the leading counties of the world that recorded the highest growth in home remittances in recent years.

\subsection{Research Problem}

During the last ten years, SBP has taken several valiant steps to increase home remittances through banking channel. It apparently seems that the extraordinary increase in the home remittances is due to the SBP's favorable policies for the Pakistani expatriate to send their money to Pakistan via banks. However, there could be some other influencing factors as well which might have boosted the volume of remittances. The phenomenon needs to be studied to find out the significance and effectiveness of the SBP's remittance policies.

\subsection{Research Objectives}

The research objectives of this study are:

1. To find out the relevant influencing factors responsible for the increase in the remittances to Pakistan.

2. To evaluate the strategies adopted by all the banks to boost home remittances in compliance to the SBP PRI directives/policy.

3. To identify the significance of SBP (PRI) - Real Time Gross Settlement System (RTGS) home remittances settlement mechanism and how was it implemented on the banking sector in Pakistan.

\subsection{Research Questions}

The research objectives/questions are:

RQ1 - What steps have been taken by SBP during the last 10 years (i.e. between 2001 to 2010 ) to boost remittances via legal channel? It will be year wise comparison?

$\mathrm{RQ2}$ - What were the reasons that triggered SBP to implement these policies during the last 10 years?

RQ3 - Is there any relationship between SBP's policies and the volume of remittances routed via banking channel during last 10 years?

RQ4 - What are the effects of SBP policies on the banks for their infrastructure development?

\subsection{Benefits of the Study}

This study could help researchers to realize the rationale of SBP policies/directives and the performance of the banking sector in boosting remittances business. It will also explore the question 'why were these policies implemented?' Were they inevitable? Does it successfully fulfill the purpose? How these policies/directives are instrumental in order to increase the volume of home remittan ces via banking sector/channel in Pakistan? This research also found the qualitative changes in the banking channels of

16 January $2012 \quad$ Volume $10 \quad$ Number $1 \quad$ Journal of Independent Studies and Research - MSSE 
remittances. Hence, this study has provided the starting point for further empirical studies to explore the other factors/variables that might have contributed in increasing the volume of home remittances in Pakistan. Also, causal studies can be navigated to determine the standard of home remittance services provided by the banks in Pakistan.

\subsection{Research Methodology}

This research aims to understand the SBP's home remittance policies and its effects on the volume of remittances and on the banking sector for the last 10 years. Given the nature of the study undertaken, it is an exploratory research.

\subsubsection{Research Design}

This research is interpretive in nature based on mixed methodologies with existing statistics. For the purpose, the year wise workers remittances record was retrieved from the archives of SBP. This remittance record was compared with the year wise SBP Home Remittance Policies implemented during 2001 to 2010 using MS Excel. This has enabled the researcher to identify relevant relationship and to evaluate its effects in terms of the percentage growth in volume of the Home Remittance e.g. SBP policy implemented in 2001 and the effects in terms of growth in remittance volume during one year.

Primary Data: The data was mainly gathered through individual interviews and focus group discussion of the Subject Matter Experts (SME). These SME were the SBP officials and senior executives of the banking sector from NBP, UBL, ABL, MCB and HBL. The data was collected through the unstructured interview questions, personal observations during formal interviews as well as informal discussions and correspondence that took place during researcher's visit to SBP and banks throughout the research.

Secondary Data: This includes Home Remittance archives, published reports, newspaper articles, books and journals gathered from the websites of State Bank of Pakistan (SBP), Asian Development Bank (ADB), World Bank (WB) and International Monetary Fund (IMF) etc. The secondary data is discussed and verified by the SME to ensure the reliability, consistency and authenticity.

\section{Literature Review}

The money send by the migrant/remitter from its host country to the country of his origin for the purpose of their family maintenance (kitchen expenses, children education etc.) that is collected by an individual receiver/beneficiary in the form of cash or in their personal bank account is known as home remittance.

Remittances over the last decade have increased steadily around the globe. As per World Bank report, out of US $\$ 414$ billion, US $\$ 316$ billion was routed to the developing countries. These remittances are sent by an estimate of 192 million migrants living in host countries (Ahmed, Sugiyarto and Jha, 2010). The World Bank asses that the annual flow of remittances are as high as one third of the GDP of the recipient countries. 


\subsection{Considerations of Workers' Remittance}

According to Mambio and Ratha (2005), the scalability of the migrant country banking system has indirect influence on the financial awareness of the migrants. The migrant might have the knowledge or could be using the product and services offered by the banks to send money to their families/beneficiaries in host country. But if the host/beneficiary country has undeveloped banking system with limited branches, it is more likely that the remitter can opt to send money back home using alternate nonbanking channels. The migrants' psychological, cultural, social, economic beliefs and characteristics in the immigrant country impact strongly to access and use banking channels (i.e. their own position in the labor market e.g. temporary/ contract, selfemployed or employee). Education level of migrant is also a factor to use banking services (i.e. aptitude to read/write, awareness host country language and basic mathematical concepts help them to access banking product and services) in the immigrant country.

\subsection{Financial and Sovereign Risk of Remittances}

Migrants are often exposed to social and financial prohibition. Most of these migrants belong to the lowermost salary group in the host countries. This phenomenon is especially true for the migrants living in groups that integrate with locals less fluently. Societal barring among settlers enhances the problems they face while utilizing the banking facilities. Due to their variable salaries and small savings, many banks perceive immigrants as unimportant customers. As these customers are considered relatively risky as their facilitation involve higher administrative cost and offer lower profit margins (Pilley, 2003).

The cost of sending money back home is relatively expensive as compared to the income and salaries of the migrants. Typically, the remitters send not more than a few hundred dollars per transition. So, the reduction in remitting fee has impact on migrant saving behavior and sending the money back home. If the remittance cost is reduced by $5 \%$ to the total value sent today, the developing countries may receive US Dollar 15 billion more as they are receiving today; that shall naturally improve the national savings, consumption, and level of investment in the economy of the recipient country.

The cost of remittances is fairly high due to the following reasons:

1. Underdeveloped banking infrastructure in the remittance receiving country.

2. Limited competition in remitting and recipient country.

3. Governmental \& Central Bank regulatory obstacles at sending and receiving countries.

4. Poor access to the banking product/services for both remittance senders and receivers.

5. Migrants facing difficulties manage necessary ID documentation to access financial services.

6. Lack of transparency in the market in terms of available key market players/services, transactional cost, exchange rate differential as the remitter or sender can't compare the per transaction cost and bargainable exchange rates.

7. The total turnaround time required to send the payment by the remitter and to receipt of payment by the beneficiary in his/her bank account or cash receipt.

\begin{tabular}{l|lll}
\hline 18 & January 2012 & Volume $10 \quad$ Number $1 \quad$ Journal of Independent Studies and Research - MSSE
\end{tabular}




\subsection{Remittances to Pakistan}

In Pakistan, due to political, law and order, poor economic growth, force majeure situations and unemployment, both skilled and unskilled people of the country are applying and trying to settle abroad. Approximately 4.23 million Pakistani immigrants are living mainly in Saudi Arabia, UAE \& GCC countries, USA and UK (Ahmed, Sugiyarto and Jha, 2010). It is estimated that seven million Pakistani migrants live abroad and the main destinations are Saudi Arabia, GCC countries, UK, USA and Canada. The migration has doubled since 2007 and the Pakistani skilled and unskilled migrants are moving steadily to Saudi Arabia, UAE \& GCC countries, USA and UK in 2009 (Kock and Sun, 2011).

Pakistan Remittance Initiative (PRI) was established in 2009 on the directives of Ministry of Finance, Ministry of Foreign Affairs and State Bank of Pakistan. This joint venture is managed by the senior officials of State Bank of Pakistan. The prime objective of PRI is to optimize the existing remittance volumes and to reduce the transactions costs of the remitters. SBP has initiated the Pakistan Remittance Initiative (PRI) to reimburse the marketing expenses of overseas financial entities that mobilize large amounts of remittances via banking channel. This shall reduce the cost of remittance borne by the Pakistan remitters working abroad.

The SBP - PRI suggestions are:

1. The financial incentives should be provided to the returning immigrant that wishes to set up small or medium size businesses.

2. The Banks should quote special exchange rate to the remitting agencies/remitters to send their money via banking channel.

3. The Banks should offer saving products/services/accounts to the Pakistani expatriates to send their remittances via banking channel.

4. To make banks more proactive and to improve the quality of remittance disbursement to the beneficiaries in Pakistan (i.e. by minimizing the remittances turnaround time at the banks). Rapid and instant processing and payment collection by the beneficiaries shall reassure immigrants to direct their payments through official channels.

PRI has established a dedicated 24/7 operational call center in order to facilitate the remitters and beneficiaries in Pakistan. The Pakistani expatriates or the beneficiaries can inquire and/or report complain(s) about their payments for the payments routed by any bank in Pakistan. The landline PTCL number is $+92-21+35208888$. A toll free number is offered to the Pakistani immigrants living in North America on the number 1-877-707-7714.

\section{Data Analysis and Presentation}

It has been found that the very foundation in the growth of home remittances volume was triggered by SBP policies that created competition among domestic banks, exchange companies and illegally operating hundi/hawala network to tap the home remittance business. There is a strong relationship between SBP's policies and the volume of remittances routed via banking channel during the last 10 years as the $R 2=0.9132$. 
Similarly, the SBP incentive scheme played a pivotal role that boosted the remittance volume exponentially as domestic banks and their foreign arrangements identified the potential of risk free home remittance business (fee-based income) that is consistent even in the current global financial turmoil. Furthermore, the foreign remitting agencies started offering free or nominal charges on remittance services to the Pakistani expatiates. Nowadays, the highest volumes of remittance are received from UAE, Saudi Arabia, USA, other GCC countries, UK, EU countries and Canada along with few others. Similarly, SBP administered the revamping of the old and identified the commencement of new home remittance arrangement for the banks from around the world while remaining meticulous through the international KYC/AML and ATF rules and regulations.

It has been found that the very foundation in the growth of home remittances volume was triggered by SBP policies that created competition among domestic banks, exchange companies and illegally operating hundi/hawala network to tap the home remittance business. There is a strong relationship between SBP's policies and the volume of remittances routed via banking channel during the last 10 years as the $R 2=0.9132$. Similarly, the SBP incentive scheme played a pivotal role that boosted the remittance volume exponentially as domestic banks and their foreign arrangements identified the potential of risk free home remittance business (fee-based income) that is consistent even in the current global financial turmoil. Furthermore, the foreign remitting agencies started offering free or nominal charges on remittance services to the Pakistani expatiates.

Nowadays, the highest volumes of remittance are received from UAE, Saudi Arabia, USA, other GCC countries, UK, EU countries and Canada along with few others. Similarly, SBP administered the revamping of the old and identified the commencement of new home remittance arrangement for the banks from around the world while remaining meticulous through the international KYC/AML and ATF rules and regulations. SBP stimulated the Pakistani banks to develop competitive IT infrastructure in the banking sector. This improved the inter-bank payment settlement system regardless of the limited banking hours and branch network coverage to facilitate payment receipts in Pakistan. Due to SBP's PRI initiative, the domestic banks started offering cash over counter payment services to the beneficiaries within minutes and bank transfer payments within 24 hours to encourage the remitters compete against hundi/hawala services. SBP devised the standards for remittance processing and complaint handling mechanism for banks that minimized payment turnaround time and facilitated the remitters/beneficiaries so that they prefer banking channel instead of hundi/hawala networks. SBP marketing incentives motivated banks and foreign remitting agencies to place Pakistani regional language speaking representatives to create awareness among the Pakistani expatriates to send payments via banking channel contributing to the noble national cause.

\section{Conclusion}

From this research, it can be concluded that the policy initiatives of the SBP have benefitted Pakistan in the quantitative aspects (i.e. increase in the volume of remittances to Pakistan) and in qualitative terms (i.e. improvement in the Pakistani banks' facilities for the remittance handling divisions). It is detected that during the period of 1990 s to 2000 the home remittance volume posted downward trend. SBP implemented several efficient policies during 2001 to 2010 that fruited in the form of annual double digit growth in the volume of home remittances (i.e. from USD \$ 983.73 million in 2000 to US \$ 8.905 billion in 2010).

\footnotetext{
20 January $2012 \quad$ Volume $10 \quad$ Number $1 \quad$ Journal of Independent Studies and Research - MSSE
} 


\section{References}

Abella, M.I. 1989, 'Policies and Practices to Promote Remittances', Philippine Labour Review, Vol. 13, No. 1, pp. 1-17.

Ahmed, V. Sugiyarto, G. \& Jha, S. 2010, 'Remittances and Household Welfare: A Case Study of Pakistan', ADB Economics Working Paper Series No. 194, http://beta.adb.org/publications/remittances-and-household-welfare-case-studypakistan?ref=data/publications

Anderloni, L., Aro E., \& Righetti, P. 2005, 'Migrants and financial services in Spain', Mimeo.

Kock, U. \& Sun, Y. 2011, 'Remittances in Pakistan - Why have they gone up, and why aren't they coming down?', IMF Working Paper Series, Middle East and Asia Department, WP/11/200, www.imf.org/external/pubs/ft/wp/2011/wp11200.pdf

Mambio, S. M. \& Ratha, D. 2005, ' Remittance Development Impact and Future Prospects', proceeding of a conference organized by Department for International Development, IMF and World Bank, Washington D.C., USA, pp. 104-118.

Nishat, M. \& Bilgrami, N. 1991, 'The Impact of Migrant Workers' Remittances on Pakistan', Pakistan Development Review, Vol. 30 No. 1, pp. 400-480.

Pakistan Remittance Initiative (PRI), http://www.pri.gov.pk/about/

Pilley C. 2003, 'Immigrants and Financial Services: Literacy, Difficult of Access, Needs and Solutions: The UK Experience', IFF - FGDA, paper prepared for the research project, European Commission - General Directorate Employment and Social Affairs, Working Paper N. 2-2004, www.microfinancegateway.org/gm/document1.9.28083/30263_file_29.pdf

Rapoport, H. \& Docquier, F. 2006, 'The Economics of Migrants' Remittances', in Handbook on the Economics of Giving, Reciprocity and Altruism, Vol. 2, pp. 1135-1198. SBP Press Release 2011, http://www.sbp.org.pk/press/2011/Remittances-10-Aug-11.pdf

Straubhaar, T. 1986, 'The Determinants of Workers' Remittances: The Case of Turkey', Weltwirtschaftliches Archive-Review of World Economics, Vol. 122, No. 4, pp. 728-740. 